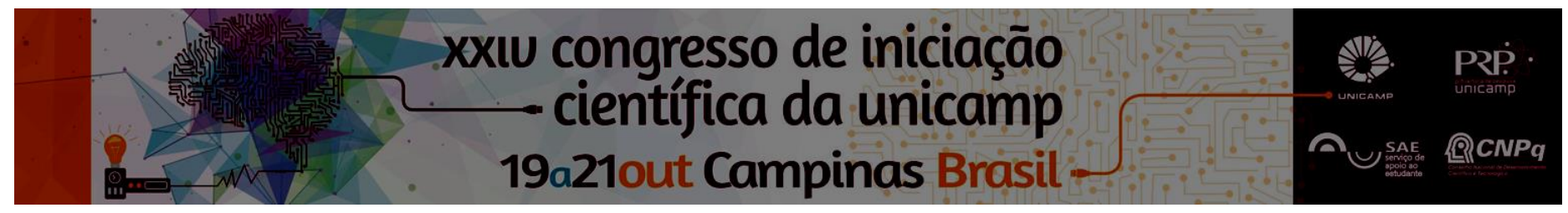

\title{
Interpretações Sobre Radiação lonizante: uma breve leitura no ensino médio.
}

\author{
Maira Lavalhegas Hallack*, Maria José P. M. de Almeida.
}

\section{Resumo}

Buscamos compreender como alunos de primeiro ano do ensino médio interpretam a radiação ionizante ao lerem em aula de física sobre o assunto. Acompanhamos aulas dessa disciplina numa turma de primeiro ano desse nível de ensino numa escola estadual de Campinas - S.P. Após um mês de acompanhamento, com autorização do professor da turma, elaboramos duas questões abertas para os alunos responderem por escrito com base na leitura de um trecho do livro "As aventuras Científicas de Sherlock Holmes" (BRUCE, 2001). Com as respostas em mãos, realizamos um "bate papo" sobre as dúvidas com a turma. Solicitamos que respondessem mais uma questão aberta sobre o que entenderam sobre o tema. Para analisar as respostas, utilizamos a noção de repetição como a entende a análise de discurso pecheutiana. Concluímos que dos alunos, $28 \%$ realizaram repetição empírica, cópia mnemônica; 36\%, formal, contar com suas palavras, sendo que $20 \%$ destes, apresentaram equívocos; $28 \%$, histórica, relacionar com suas histórias de vida, incluindo outras leituras, sendo que $50 \%$ com equívocos. Após a conversa, as interpretações do tema aproximaram-se mais de noções científicas. Destacamos a importância da mediação do professor em aula.

\section{Palavras-chave:}

Interpretação, Radiação Ionizante, Leitura.

\section{Introdução}

Muitos pesquisadores da área de Ensino de Ciências defendem a importância da leitura em aulas de disciplinas dessa área. A leitura é importante não apenas em aulas de português, mas de ciências. (CASSIANI, 2012). Consideramos que é uma maneira de introduzir os alunos do ensino médio a física moderna e contemporânea. Especialmente, no ensino dessa disciplina, é importante que haja um diálogo entre a linguagem matemática e a linguagem comum. Possibilita aos alunos nos diferentes ciclos de ensino o contato com a física como cultura e, contribui para uma formação mais ampla e cidadã dos estudantes. Nesse sentido, é importante a abordagem de diferentes tipos de discurso, cada um destes caracterizado por suas diferentes relações entre forma e conteúdo. (ORLANDI, 1996). Esta é uma maneira de alcançar os diferentes estudantes que compõem a sala de aula.

Buscamos compreender possíveis interpretações que alunos de primeiro ano de ensino médio, de uma escola estadual do município de Campinas - S.P., fazem ao lerem um trecho da obra de Colin Bruce (2001) sobre radiação ionizante. Para análise de respostas a questões escritas utilizamos como apoio teórico-metodológico a análise do discurso de vertente originada com Michel Pêcheux. Nos baseamos em publicações no Brasil, especialmente, de Eni Orlandi, utilizamos as noções de repetição da autora, para nossa análise.

\section{Resultados e Discussão}

O professor de física, cujas aulas acompanhamos, como a maioria dos professores de física não propunha atividades de leitura (BERTOLDO et al, 2014). Realizava suas aulas com base em exercícios repetitivos, onde os alunos apenas copiavam da lousa. Suas provas eram com consultas ao caderno e a cópia do livro didático era uma das atividades avaliativas. Com base na perspectiva de Piassi (2013), tentamos fazer do texto lido pelos alunos o conteúdo da aula, tendo para isso apenas uma semana. Apresentamos alguns resultados.

Tabela 1: Alguns Resultados

\begin{tabular}{|c|c|c|}
\hline Repetição & \multicolumn{2}{|l|}{$\%$} \\
\hline Não responderam & \multicolumn{2}{|l|}{$8 \%$} \\
\hline Empírica - Cópia mnemônica & \multicolumn{2}{|l|}{$28 \%$} \\
\hline \multirow[t]{2}{*}{ Formal - falar com as suas palavras } & Sem equívoco & $28 \%$ \\
\hline & Com equívoco & $8 \%$ \\
\hline \multirow{2}{*}{$\begin{array}{l}\text { Histórica - relacionar com suas } \\
\text { memórias, incluindo de leituras }\end{array}$} & Sem equívoco & $14 \%$ \\
\hline & Com equívoco & $14 \%$ \\
\hline
\end{tabular}

\section{Conclusão}

Após o "bate-papo" notamos a importância da mediação do professor, pois as respostas equivocadas diminuíram. A leitura mediada contribuiu para interpretações mais próximas do texto.

\section{Agradecimentos}

Agradecimento ao $\mathrm{CnPq}$ e ao professor e alunos que disponibilizaram suas aulas para nossa pesquisa.

BERTOLDO, R. R.; CUNHA, M. B. ; STRIEDER, D. M. ; SILVA, A. S. . A leitura de divulgação científica na escola, existe?. In: Simpósio sobre Divulgação Científica na sala de aula, 2014, São Paulo. caderno de Resumos Simpósio sobre Divulgação Científica na sala de aula: perspectivas e possibilidades, 2014.

BRUCE, C. As aventuras científicas de Sherlock Holmes: o paradoxo de Einstein e outros mistérios. Rio de Janeiro: Jorge Zahar, 2001

CASSIANI, S., GIRALDI, P. M., LINSINGEN, I. É possível propor a formação de leitores nas disciplinas de Ciências Naturais? Contribuições da análise de discurso para a educação em ciências. Educação Teoria e Prática, v.22, n.40, (2012) Disponível em: http://www.periodicos.rc.biblioteca.unesp.br/index.php/educacao/

ORLANDI, E. Interpretação: autoria, leitura e efeitos do trabalho Simbólico, $4^{\mathrm{a}}$ Edição. Campinas: Pontes, 1996.

PIASSI, L. P. C. Interfaces Didáticas entre Cinema e Ciência - Um Estudo a Partir de 2001: Uma Odisseia no Espaço. 1. ed. São Paulo: Livraria da Física, 2013. v. 1. 2 